\title{
Investigation of Epidermal Growth Factor, Tumor Necrosis Factor-alpha and Thioredoxin System in Rats Exposed to Cerebral Ischemia
}

\author{
Melike Erol-Demirbilek ${ }^{* 1,2}$, Nedret Kilic ${ }^{1}$, Hatice Ferhan Komurcu ${ }^{3}$ \\ ${ }^{1}$ Department of Medical Biochemistry, Medical Faculty, Gazi University, 06500 Besevler, Ankara, Turkey, \\ ${ }^{2}$ Republic of Turkey Ministry of Food,Agriculture and Livestock, Ankara, Turkey, \\ ${ }^{3}$ Department of Neurology, Ankara Ataturk Training and Research Hospital, 06800 Bilkent, Ankara, Turkey
}

\begin{abstract}
Background: Thioredoxin reductase (TrxR), epidermal growth factor (EGF) and tumor necrosis factor- $\alpha(T N F-\alpha)$ have neuroprotective/neurotoxic effects in cerebral ischemia. We aimed to investigate the TrxR activity, EGF and $T N F-\alpha$ levels in cerebral ischemic, sham-operated and non-ischemic rat brains.

Methods: Sprague-Dawley rats divided into three groups. Rats in control group were not subjected to any of treatments and their brains were removed under anesthesia. Middle cerebral arters were exposed but not occluded for the sham-operated rats. Animals were subjected to permanent middle cerebral arter occlusion (MCAO) in MCAO-operated group. The rats were decapitated at 16 hours (h), $48 \mathrm{~h}$ and $96 \mathrm{~h}$ after sham operation and focal cerebral ischemia. TrxR activities, EGF and TNF- $\alpha$ levels were measured in ischemic and non-ischemic hemispheres for all groups.

Results: In group MCAO, TrxR activities were significantly low at $48 \mathrm{~h}$ in ischemic hemisphere in comparison to control. After the $48 \mathrm{~h}$, a remarkable increase was observed at $96 \mathrm{~h}$. EGF and TNF- $\alpha$ levels were substantially high at 96 h in group $M C A O$ of ischemic brain.

Conclusion: TrxR activity was reduced by oxidative stress which was formed by ischemia. EGF levels increased to exhibit neurotrophic and neuroprotective effects. After ischemia, TNF- $\alpha$ levels increased as a response to the tissue damage. Further studies with a higher number of experimental subjects and shorter or longer periods such as from first 30 minutes up to 3 months may be more informative to show the time-dependent variations in TrxR, EGF and $T N F-\alpha$ in cerebral ischemic injury.
\end{abstract}

Keywords: thioredoxin reductase, epidermal growth factor, tumor necrosis factor- $\alpha$, cerebral ischemia.

Received: 23 $3^{\text {th }}$ March 2016; Accepted: 16 July 2016; Published: $25^{\text {th }}$ July 2016.

\section{Introduction}

Cerebral ischemia induces a variety of changes in the brain: consumption of energy substrates, inflammatory alterations, increased intracellular calcium and reduced amount of cerebral blood flow. These alterations are necessary for neuronal functions. Resulting biochemical processes such as energy failure, loss of cell ion homeostasis,

* Corresponding author: Melike Erol-Demirbilek, Biotechnology Research Center. The Ministry of Food, Agriculture and Livestock, Field Crops Research Institute, Istanbul Yolu 5.km, Yenimahalle, Ankara, Turkey. e-mail: melikerol@yahoo.com 
increased intracellular calcium, excitotoxicity and free radical-mediated toxicity are related to the depth and duration of ischemia (1).

Brain antioxidant defense system involves redox compounds and antioxidant enzymes. The redox compounds have low molecular weight such as ubiquinone, tocopherols, ascorbic acid, lipoic acid, NADPH, NADH and GSH. The antioxidant enzymes comprise of catalase, cytosolic and mitochondrial superoxide dismutases, peroxidases, thioredoxin isozymes and glutaredoxins (2).

The thioredoxin system consists of thioredoxin (Trx) and NADPH-dependent thioredoxin reductase (TrxR, 1.6.4.5.). TrxR belongs to a family of homodimeric pyridine nucleotide-disulfide oxidoreductases. Each monomer includes an active site containing a redox-active disulfide (Cys-Val-Asn-Val-Gly-Cys), a NADPH binding site and a FAD prosthetic group. Electrons are transferred from NADPH to the active-site disulphide of TrxR via FAD. Thioredoxin, which is TrxR's characteristic substrate, is reoxidized at the same time. The thioredoxin system is protective against oxidative and ischemic stress and plays a crucial role in a myriad of cellular functions via redox regulation $(3,4)$.

Epidermal growth factor (EGF) is a small peptide and it has mitogenic effects on different cells. EGF induces the phosphorylation reactions and alters the morphology of various cell lines derived from the nervous system. EGF plays a role as neurotransmitter or neurotrophic molecule $(5,6)$.

Tumor necrosis factor (TNF- $\alpha$ ) is a cell signalling protein (cytokine) and its synthesis is induced by ischemic or traumatic brain injury. TNF- $\alpha$ levels elevate in inflammatory disorders of CNS. TNF- $\alpha$ exacerbates focal ischemic brain damage and blocking endogenous TNF might be neuroprotective (7).
Oxidative stress caused by cerebral ischemia can suppress the antioxidant enzyme activities. These enzyme activities can increase as a response to long-term injury. The protective effects of EGF on neurons may be more important in long-term permanent ischemia. It is thought that TNF- $\alpha$ aggravates the ischemic brain damage. Due to these reasons, we aimed to investigate the activity of TrxR, the levels of EGF and TNF- $\alpha$ in prolonged ischemia.

\section{Material and methods}

\section{Animals}

All animal procedures were approved by the Animal Research Committee of Gulhane Military Medical Academy Training Hospital (GATA), Ankara. Animals were prepared in GATA Animal Research Laboratory. A total of 47 male Sprague-Dawley rats ( $\mathrm{n}=6$ to 8 per each group) weighing about 200-300 g were used in the study. At the beginning of the study, we started with $\mathrm{n}=8$ for each group but some of the animals died during experimental and operational studies. That's why, the number of animals per each group was different. Rats were allowed free access to food and water under a controlled enviroment (12 hours (h) dark/12 h light cycle, $20-22^{\circ} \mathrm{C}$, constant humidity) before and after all procedures.

In this study rats were divided into 3 groups. Control groups were not subjected to any of middle cerebral artery occlusion (MCAO) treatments and brains were removed under anesthesia (group 1). For the sham-operated rats (group 2), the middle cerebral arterys were exposed to sham operation but not occluded. After closing the skin incision, rats were allowed free access to food and water. Rats were decapitated at 16 hours (h), $48 \mathrm{~h}$ and $96 \mathrm{~h}$ after sham treatment. In group MCAO (group 3), animals were exposed to permanent 
middle cerebral artery occlusion and decapitated at $16 \mathrm{~h}, 48 \mathrm{~h}$ and $96 \mathrm{~h}$ following occlusion. Brains were removed quickly.

Permanent occlusion of MCAO was achieved by using the described method in the literature (8-10). Briefly, left common carotid artery was exposed through a midline vertical incision under anaesthesia $(100 \mathrm{mg} / \mathrm{kg}$ ketamine and $5 \mathrm{mg} /$ $\mathrm{kg}$ xylazine). The temporal muscle was removed and a $2 \mathrm{~cm}$ burr hall was drilled with zygomatic arc on bone union region. The left middle cerebral artery was detected and then the artery was cauterized by using bipolar cauter and cut by microscissors. MCAO was confirmed with microscopic inspection. Rapidly removed brains were washed with $0.9 \%$ saline and then stored at $-80^{\circ} \mathrm{C}$ until use. All the following biochemical analyses were carried out on right (non-ischemic) and left (ischemic) hemisphere.

\section{Measurement of thioredoxin reductase activity}

The brain tissues were homogenized in $50 \mathrm{mM}$ Tris-HCL, pH 7.5, 1 mM EDTA and centrifuged. The supernatants were adjusted to $\mathrm{pH} 5.0$ with 1.0 $\mathrm{M}$ acetic acid. The precipitates were removed by centrifugation and the supernatants were adjusted to $\mathrm{pH} 7.5$ with $1.0 \mathrm{M} \mathrm{NH}_{4} \mathrm{OH}$. Protein measurements were carried out according to Lowry (11). All supernatants were heated to $60^{\circ} \mathrm{C}$ and then rapidly cooled to $+4^{\circ} \mathrm{C}$. The precipitates were removed by centrifugation. Ammonium sulfate was added to $85 \%$ saturation and the precipitates were collected by centrifugation. The precipitates were dissolved in TE buffer and filtered through an ultrafiltration membrane by centrifugation. Upper volumes were used for thioredoxin reductase activity. 5.5'-dithiobis (2-nitrobenzoic acid) (DTNB) was reduced by TrxR via NADPH. As a result of this reaction, TNB (5'-thionitrobenzoic acid) was produced. TNB is a yellow acid and has an absorbance maximum at $412 \mathrm{~nm}$ (12). Reaction mixture $(500 \mu \mathrm{l})$ was added to the spectrophotometry cuvettes [(NADPH $(40 \mathrm{mg} / \mathrm{ml}$ in water) $50 \mu \mathrm{l}$ of; $0.2 \mathrm{M}$ EDTA $0.5 \mathrm{ml} ; 1.0 \mathrm{M}$, pH 7.0 potassium phosphate buffer $1.0 \mathrm{ml}$; DTNB (25 mg/ $\mathrm{ml}$ in $99.5 \%$ ethanol) $0.8 \mathrm{ml}$; BSA (bovine serum albumin; $20 \mathrm{mg} / \mathrm{ml}) 100 \mu \mathrm{l}$ and water to a final volume of $10 \mathrm{ml}$. Protein sample was added to sample cuvette $(100 \mu \mathrm{l})$ and buffer was added to the reference cuvette $(100 \mu \mathrm{l})$. The reaction was followed at $412 \mathrm{~nm}$ for $3 \mathrm{~min}$. $1 \mathrm{IU}$ (International Unit) TrxR activity produced $1 \mu$ moles of TNB in $1 \mathrm{~min}$ at constant temperature and $\mathrm{pH}$. Since TNB had an absorbance maximum at $412 \mathrm{~nm}$ with an extinction coefficient of $13,600 \mathrm{M}^{-1} \mathrm{~cm}^{-1}$, $\Delta \mathrm{A}=$ am. $\Delta \mathrm{c} .1$ equation was used to calculate the $\mu$ moles of TNB produced $/ \mathrm{min}$. The results were expressed as $\mathrm{U} / \mathrm{mg}$ tissue protein.

\section{Measurement of EGF and TNF- $\alpha$ levels}

The brain tissue TNF- $\alpha$ and EGF levels were measured using commercial enzyme-linked immunosorbent assay (ELISA) kits (CytElisa and Biosource respectively). All samples were tested in duplicates. The concentrations of TNF- $\alpha$ and EGF were calculated from a standard curve and expressed in $\mathrm{pg} / \mathrm{mg}$ tissue protein.

\section{Statistical analysis}

Kruskal Wallis variance analysis and Mann-Whitney U test were used by the SPSS 11.5 programme written for Windows. Values of $\mathrm{p}<0.05$ were regarded as significant. To investigate the correlations between all groups and parameters, Spearman Correlation analysis was performed.

\section{Results}

There was no statistically remarkable difference between the sham-operated and the control group for the TrxR activities in ischemic region (Figure 1). In group MCAO of left hemisphere, tis- 


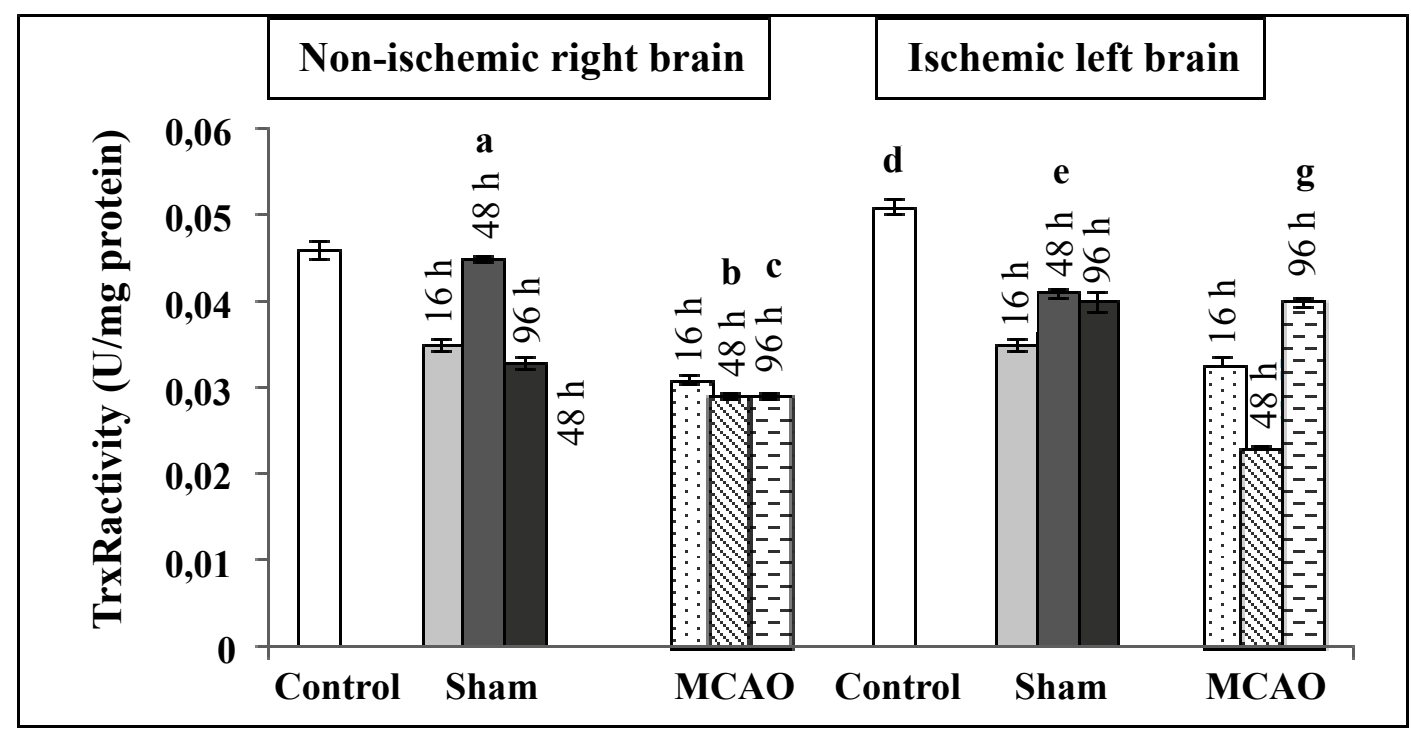

Figure 5. Thioredoxin reductase activities of control, sham and MCAO groups in the non-ischemic and ischemic hemispheres. Statistically significant difference was observed when "a" was compared to "b" and "c" $(p<0.05)$, and when "f $f$ " was compared to "d," "e" and "g" $(p<0.05)$.

sue enzyme activities at $48 \mathrm{~h}$ were significantly lower when compared to $96 \mathrm{~h}$ in the same group and the control group, $\mathrm{p}<0.05$. Enzyme activities reached their highest point at $96 \mathrm{~h}$. There was no statistically notable difference between the group 1,2 and the control group concerning TrxR activities in the non-ischemic region. Increased enzyme activities were observed merely at $48 \mathrm{~h}$ in sham-operated group compared to $48 \mathrm{~h}$ and $96 \mathrm{~h}$ in MCAO group, $\mathrm{p}<0.05$.

EGF levels of ischemic brain tissue dramatically soared at $96 \mathrm{~h}$ in group MCAO, $\mathrm{p}<$ 0.05 (Figure 2). This was nearly a twofold increase when compared with the control. Similar amounts of epidermal growth factor were found at $16 \mathrm{~h}$ and $48 \mathrm{~h}$ in group MCAO, which were not statistically significant. It is also revealed that EGF values of sham group fluctuated meaninglessly in the ischemic area. Growth factor levels rose gradually in the MCAO group, while they fell slowly in the sham group of non-ischemic hemisphere. EGF levels at $96 \mathrm{~h}$ after sham treat- ment decreased significantly when compared with the $16 \mathrm{~h}$ in the same group and the control group, $\mathrm{p}<0.005$.

There was no statistically remarkable difference in the TNF- $\alpha$ levels between the ischemic/ sham groups and the control group. It was seen that the TNF- $\alpha$ levels hit a peak at $96 \mathrm{~h}$ after MCAO in the ischemic region. This level was statistically significant only when compared to $48 \mathrm{~h}, \mathrm{p}<0.05$. TNF- $\alpha$ values at $48 \mathrm{~h}$ were higher than $16 \mathrm{~h}$ in sham operated group, $p<0.008$. Levels of tumor necrosis factor- $\alpha$ dipped slowly in the non-ischemic area which were not significant (Figure 3).

According to the results of the Spearman correlation analysis, there was a positive correlation between TNF- $\alpha$ and EGF levels in the ischemic area (Figure 4).

\section{Discussion}

Cerebral ischemia leads to important pathophysiological processes such as energy failure, loss of cell ion homeostasis, acidosis, increased in- 


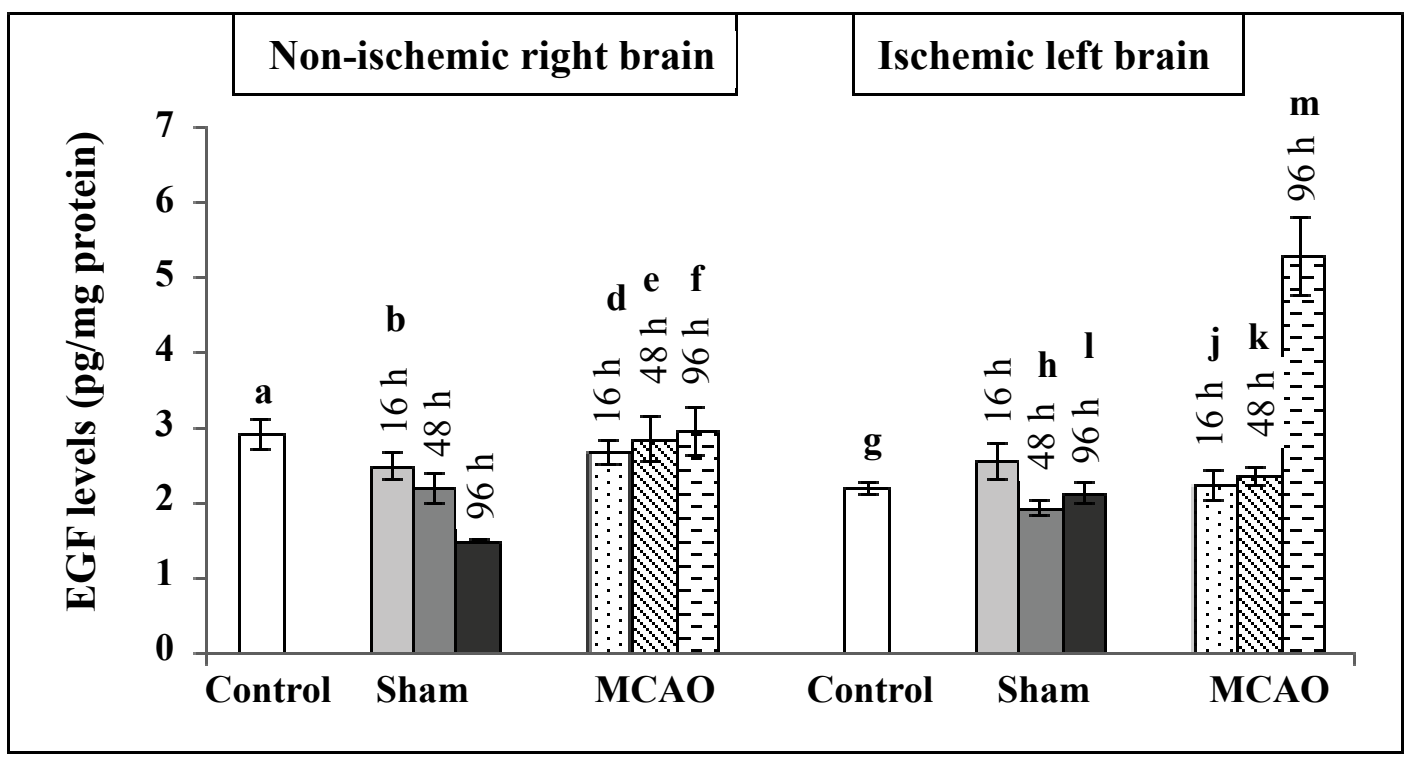

Figure 2. Statistical results of EGF levels in all groups. "c" was be significantly lower when compared to "a," "b," "d," "e" and "f" (p< 0.005); while "m" was significantly higher than "g," "h," "1," "j" and "k" $(p<0.05)$.

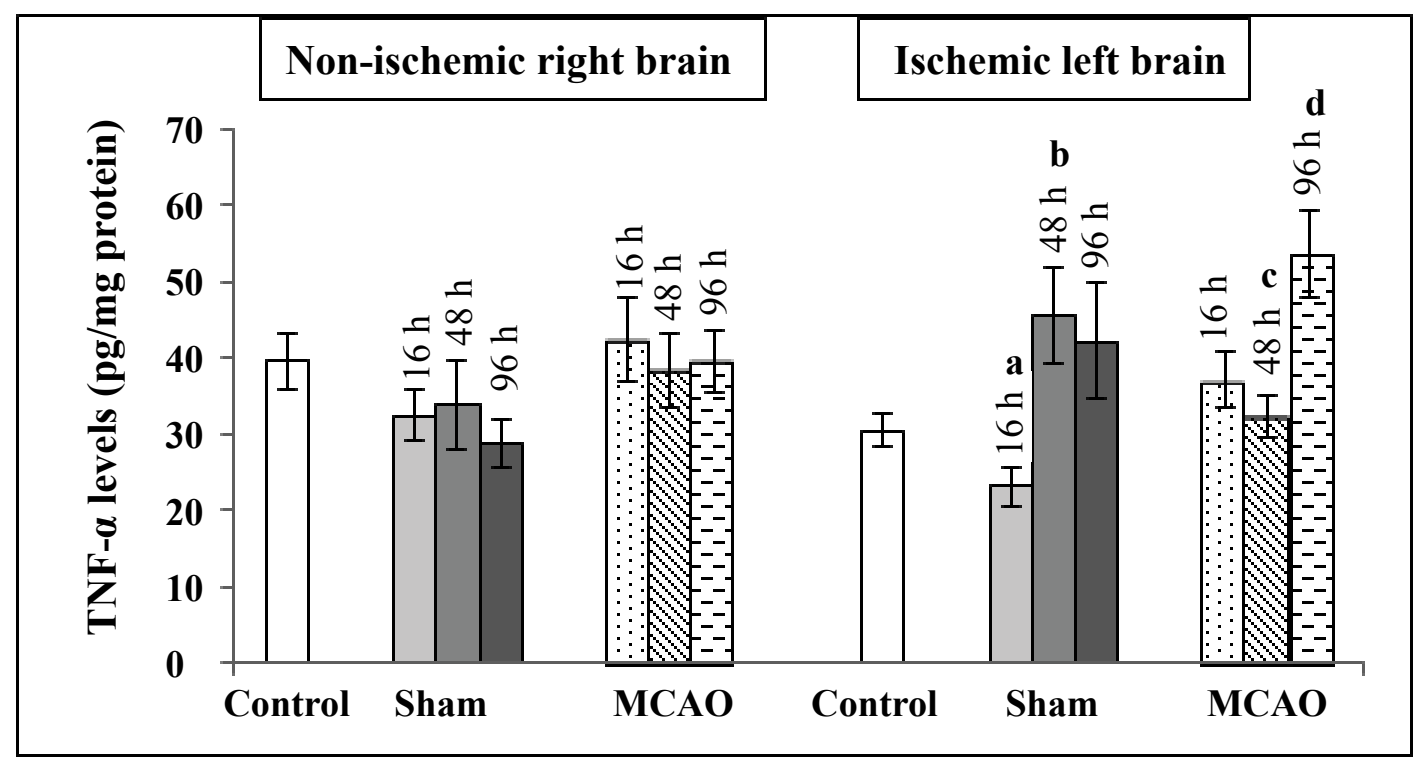

Figure 3. The results of TNF- levels in all groups. Significant difference between "a," "b" and "d" (respectively $p=0.008$ and $p=0.002)$, and between "c" and " $d$ " $(p<0.05)$. 


\begin{tabular}{|l|c|c|c|c|c|c|}
\hline right & $\begin{array}{c}\text { left } \\
\text { EGF }\end{array}$ & $\begin{array}{c}\text { right } \\
\text { TNF- } \alpha\end{array}$ & $\begin{array}{c}\text { left } \\
\text { TNF- } \alpha\end{array}$ & $\begin{array}{c}\text { right } \\
\text { TrxR }\end{array}$ & $\begin{array}{c}\text { left } \\
\text { TrxR }\end{array}$ \\
\hline EGF & $\ldots \ldots \ldots \ldots$ & r: 0.172 & r: -0.095 & r: 0.316 & r: 0.120 & r: 0.046 \\
p: 0.443 & p: 0.673 & p: 0.152 & p: 0.596 & p: 0.840 \\
\hline left & r: 0.172 & $\ldots \ldots \ldots \ldots$ & r: -0.034 & r: $0.618 * *$ & r: -0.016 & r: 0.015 \\
EGF & p: 0.443 & & p: 0.879 & p: 0.002 & p: 0.942 & p: 0.946 \\
\hline right & r: -0.095 & r: -0.034 & $\ldots \ldots \ldots$ & r: 0.145 & r: -0.104 & r: -0.319 \\
TNF- $\alpha$ & p: 0.673 & p: 0.879 & & p: 0.519 & p: 0.644 & p: 0.148 \\
\hline left & r: 0.316 & r: $0.618 * *$ & r: 0.145 & $\ldots \ldots \ldots$ & r: -0.086 & r: 0.012 \\
TNF- $\alpha$ & p:0.152 & p: 0.002 & p: 0.519 & & p: 0.702 & p: 0.958 \\
\hline right & r: 0.120 & r: -0.016 & r: -0.104 & r: -0.086 & $\ldots \ldots \ldots$ & r: 0.418 \\
TrxR & p: 0.596 & p: 0.942 & p: 0.644 & p: 0.702 & & p: 0.053 \\
\hline left & r: 0.046 & r: 0.015 & r: -0.319 & r: 0.012 & r: 0.418 & $\ldots \ldots \ldots$ \\
TrxR & p: 0.840 & p: 0.946 & p: 0.148 & p: 0.958 & p: 0.053 & \\
\hline
\end{tabular}

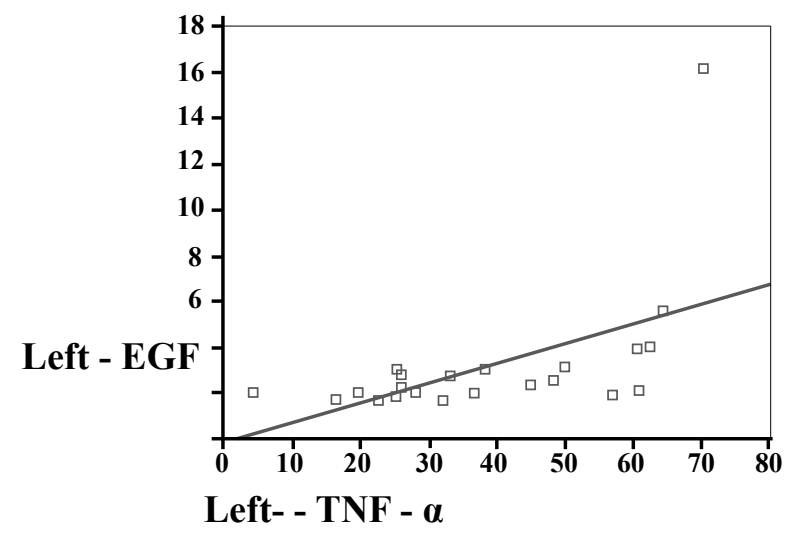

Figure 4. The results of Spearman correlation analysis for the control and ischemic groups. right $=$ non-ischenic brain, left $=$ ischemic brain, ** -indicated a strong correlation.

tracellular calcium, excitotoxicity and free radical-mediated toxicity (1). An important loss of neuronal electrical function takes place when cerebral blood flow falls below 16 to $18 \mathrm{ml} / 100 \mathrm{gm} /$ minute (13). Extracellular $\mathrm{K}^{+}$and intracellular $\mathrm{Ca}^{2+}$ levels increase if cerebral blood flow is reduced below 10 to $12 \mathrm{ml} / 100 \mathrm{gm} /$ minute and afterwards neuronal death or infarction oc- curs within 1 to 3 hours $(1,14)$. Free cytosolic intracellular calcium concentration $\left(\mathrm{Ca}^{2+}\right)$ rises remarkably after the deficiency of the calcium pump function which depends on ATP depletion. In ischemia, many of the degradation enzymes are activated by the raised intracellular calcium. Increased free radical production not only occurs during reperfusion, but also during is- 
chemia. Free radicals are important in long term ischemia as well (1). It is indicated that free radicals contribute to brain lesions and ischemia-induced free radical damage $(15,16)$.

MCAO gives rise to the increased intracellular calcium and excessive free radicals. These cellular changes cause brain damage and impairments. Sanderson et al. (17) indicated that superoxide anion led to neuronal death by means of various signalling pathways in cerebral ischemia. Nagayama et al. (18) observed that oxidative DNA damage soared significantly in the peri-infarct region after permanent MCAO. Similarly, Liu et al. (19) reported that oxidative DNA damage was observed at $16 \mathrm{~h}$ after permanent focal ischemia. This delay might have been a cause of the increased accumulation of ROS-generating factors in these regions after ischemia as time passes (18).

Increased production of free radicals during ischemia represses the cell defenses. Oxidant/ antioxidants studies in brain tissue showed an early oxidative stress in 30-60 minutes after permanent ischemia. Oxidative stress is characterized by concentrations of antioxidant molecules as well as by an increase in malondialdehyde (MDA) levels. Free radical production can continue from the onset hours up to 21 days of permanent MCAO. Ischemic damage caused by free radical production, inhibits the antioxidant enzymes activities (20). Takagi et al. (21) found that SOD activities of rat brain tissues was low markedly at 30 minutes, 4,24 and $48 \mathrm{~h}$ after the permanent MCAO.

In the present study, we showed that the TrxR, which is an antioxidant enzyme, exhibited a decrease conspicuously in group MCAO of ischemic hemisphere (left) when compared to the control group. However, this decline was statistically significant only at $48 \mathrm{~h}$. According to this result, ischemic injury repressed the TrxR activity effectively. Antioxidant enzyme activities might be diminished due to accumulated re- active oxygen species in this area. Interestingly, it was observed that the enzyme activity reached a high level at $96 \mathrm{~h}$ and this was statistically significant when compared to $48 \mathrm{~h}$.

We have not encountered enough studies with regard to the TrxR activities at $96 \mathrm{~h}$ after permanent ischemia. Since we also aimed to research the alterations in prolonged days of ischemia, an elevated TrxR at $96 \mathrm{~h}$ after ischemia was important and might be related to neuronal regeneration. Neuroprotective impacts may be increased at this time and start to exhibit regenerative effects. The total antioxidant status of brain tissue at $96 \mathrm{~h}$ after MCAO should be better investigated and supported by further studies.

We also determined low TrxR activities in the non-ischemic region as in Nagayama et al. (18). We believe that the oxidative stress might be accumulated in the non-ischemic regions time-dependently.

Free radical toxicity takes place by cerebral blood flow deficiency and following imroving processes. So, we did not expect high TrxR enzyme activities in the beginning hours and days of ischemia. Intracellular calcium ions may have increased and contributed to this repression. Because, calcium ions exhibit a dose-dependent inhibitory effect on TrxR activity. TNF- $\alpha$ had probably rushed up this situation.

Presumably, Trx expression was induced immediately after the oxidative damage in cerebral ischemia. Trx was reduced by TrxR and afterwards deteriorated conditions started the recovery. In this way, Trx system (especially along with the effect of selenocystein group of TrxR) reduced the intracellular disulfides which was generated by ROS and tried to diminish the ROS levels directly. Also Trx-TrxR system regenerated the thiol groups and led to the start signaling cascade for transcription of genes that are encoded by antioxidant proteins. All these processes have critical importance for defence system. Because of these 
reasons, enzyme activity might have soared in the fourth day after MCAO in our research.

Likewise, Sermet et al. (22) observed the time-dependent changes in antioxidant enzymes activities after focal cerebral ischemia. There were no alterations in superoxide dismutase (SOD) and catalase (CAT) activities at $3 \mathrm{~h}$ after MCAO in ischemic brain. However, the antioxidant enzyme activities diminished noticeably at $24 \mathrm{~h}$ and later returned to the baseline at $48 \mathrm{~h}$ after ischemia, then an excessive increase was observed at $72 \mathrm{~h}$ in post-ischemia. Mahadik et al. (23) demonstrated that, ischemic brain tissue was vulnerable to radical damage up to $72 \mathrm{~h}$ following ischemia because of the decreased antioxidant enzyme activities. Thereafter, these enzyme activities raised and exhibited a protective role against this damage.

Decreased EGF and increased TNF- $\alpha$ synthesis trigger the myelinolytic lesions in the central nervous system. EGF has positive effects on proliferation and/or differentiation of neurons (24). Activated EGF receptor (EGFR) by EGF reduces the cytotoxic effect of TNF- $\alpha$ in some brain tumors (25). A biological antagonism between the EGF and TNF- $\alpha$ in the central nervous system is considered widely, even if Ahnstedt et al. (26) recorded that both EGF and TNF- $\alpha$ were active in ischemia.

Most growth factors have protective effects against excitotoxic/ischemic damage. Co-treatment EGF affects the clinical and pathological outcomes in brain ischemia models (27). It was observed that nerve growth factor-transgenic (NGF-tg) mice had an intrinsic resistance against the oxidative stress after MCAO. Their superoxide dismutase and glutathione transferase activities in brain tissue were high (28). Larpthaveesarp et al. (29) determined that EGF prevented the death of CNS neurons and played an important role in protecting neurons from various injuries. In the study of Naylor et al (30), EGF mRNA levels rose significantly between
$24 \mathrm{~h}$ and $72 \mathrm{~h}$ and returned to normal levels at 7 days after MCAO in rats.

The present study showed that the EGF levels of ischemic brain area increased dramatically at $96 \mathrm{~h}$ in comparison to the control group. This marked increase at $96 \mathrm{~h}$ might be related to neuroprotection effect of EGF. There was a considerable decline merely at $96 \mathrm{~h}$ after sham treatment in the non-ischemic area. It was seen that middle cerebral artery occlusion reduced the epidermal growth factor markedly in this region. Thereby, this could be considered the lack of neuroprotection in non-ischemic area. There was not enough information in respect of the brain regeneration in prolonged ischemia. Measurement of EGF levels at shorter intervals between $48 \mathrm{~h}$ and $96 \mathrm{~h}$ would be benefical for understanding its role in prolonged ischemia.

It is known that EGF stimulates the expression of antioxidant enzymes such as glutathione reductase and SOD. Another possible way of neuroprotective effect of EGF is to up-regulate the calcium-binding proteins $(31,32)$. EGF may have supported the increase of TrxR expression in the further period of ischemia in these ways. TrxR activities and EGF levels increased at $96 \mathrm{~h}$ after ischemia to show neuroprotective effects. These effects should be meaningful in the prolonged hours/days of permanent ischemia.

TNF- $\alpha$ levels of brain tissue and cerebrospinal fluid raise in focal cerebral ischemia. TNF- $\alpha$ stimulates the focal ischemic brain injury and suppressed endogenous TNF- $\alpha$ provides cerebroprotection. $\mathrm{Tu}$ et al. $(33,34)$ found that TNF- $\alpha$ and IL- $1 \beta$ levels elevated after permanent MCAO. Jin et al. (35) demonstrated that TNF- $\alpha$ mRNA increased at $1 \mathrm{~h}$ and hit a peak at $12 \mathrm{~h}$ after permanent MCAO. This elevation was observed for five days. Katayama et al. (36) reported an increase on expression of TNF- $\alpha$ at $24 \mathrm{~h}$ after permanent MCAO treatment, however 
the others (37-39) recorded the increase in days 4-6 post trauma.

TNF- $\alpha$ is known to exacerbate the ischemic brain injury; however, the mechanism of this process is unknown. Doll et al. (40) showed for the first time that, TNF- $\alpha$ gave rise to deterioration of neuronal mitochondrial functions mediated by tumor necrosis factor receptor 1 (TNF-R1). These neurotoxic effect of TNF- $\alpha$ caused the caspase activation, mitochondrial membrane potential collapse and mitochondrial release of cytochrome c. Similarly, in our study TNF- $\alpha$ might have displayed such a neurotoxic effect. To clarify these mechanisms more detailed studies should be carried out.

In this study, there was no remarkable difference in TNF- $\alpha$ levels between the ischemic/ sham groups and the control group. However, there was a statistically considerable increase at $96 \mathrm{~h}$ in comparison to $48 \mathrm{~h}$ after ischemia in left brain hemisphere. TNF- $\alpha$ levels in the right brain tissue were not influenced from the permanent MCAO process. The role of TNF- $\alpha$ in ischemia/ stroke is still controversial. Further studies with shorter or longer periods can be more informative in showing time-dependent variations of TNF- $\alpha$ levels in cerebral ischemia. TNF- $\alpha$ synthesis was induced in focal cerebral ischemia in our study. Afterwards, TNF- $\alpha$ triggered the ischemic injury noticeably. At this stage, TNF- $\alpha$ might lead to the accumulation of peroxidation/ oxidation products in brain tissue.

TNF- $\alpha$ down-regulates the growth factors by way of performing the inactivation of growth factor receptors or preventing the transmission of signals. EGF may have been affected in the initiation of ischemia by these pathways in our study. Because of the antagonist effect between EGF and TNF- $\alpha$., EGF may have reduced the TNF- $\alpha$ cytotoxicity.

To sum up, TrxR activities were repressed effectively at $48 \mathrm{~h}$ after MCAO and then enzyme activies began to increase prominently at $96 \mathrm{~h}$.
EGF levels rocketed substantially at $96 \mathrm{~h}$ following MCAO. TNF- $\alpha$ levels also increased at $96 \mathrm{~h}$ when compared to $48 \mathrm{~h}$ in group MCAO of the ischemic brain.

\section{Conclusion}

Our findings show that TrxR activities, EGF and TNF- $\alpha$ levels alter as a response of the oxidative stress occurred by means of cerebral ischemia. These alterations depend on the process of ischemia in the beginning/prolonged hours, free radical toxicity and intracellular oxidant/antioxidant status. As mentioned, these parameters can affect each other. Future studies with more parameters and various periods (from the first minutes to months) could be done to show the time-dependent variations in TrxR activites, EGF and TNF- $\alpha$ levels in permanent cerebral ischemia.

\section{Acknowledgement}

This study was supported by grants from the Department of Scientific Research Projects (project no. 11/2004-07) of Gazi University, Ankara, Turkey.

\section{References:}

1. McDonald RL, Stoodley M. Pathophysiology of cerebral ischemia. Neurol Med Chir. 1998 Jan; 38(1):1-11. DOI: $10.2176 /$ nmc.38.1.

2. Lu J, Holmgren A. The thioredoxin antioxidant system. Free Radic Biol Med. 2014 Jan;66:75-87. DOI: 10.1016/j.freeradbiomed.2013.07.036.

3. Korge P, Calmettes G, Weiss JN. Increased reactive oxygen species production during reductive stress: The roles of mitochondrial glutathione and thioredoxin reductases. Biochim Biophys Acta. 2015 Jun-Jul;1847(6-7):514-25. DOI: 10.1016/j. bbabio.2015.02.012.

4. Aon-Bertolino ML, Romero JI, Galeano P, Holubiec M, Badorrey MS, Saraceno GE, et al. Thioredoxin and glutaredoxin system proteins-immunolocalization in the rat central nervous system. Biochim Biophys Acta. 2011 Jan;1810(1):93-110. DOI: 10.1016/j.bbagen.2010.06.011. 
5. Oliveira SLB, Pillat MM, Cheffer A, Lameu C, Schwindt TT, Ulrich H. Functions of neurotrophins and growth factors in neurogenesis and brain repair. Cytometry A. 2013 Jan;83(1)76-89. DOI: 10.1002/cyto.a.22161.

6. Ma XL, Liu KD, Li FC, Jiang XM, Jiang L, Li HL. Human mesenchymal stem cells increases expression of $\alpha$-tubulin and angiopoietin 1 and 2 in focal cerebral ischemia and reperfusion. Curr Neurovasc Res. 2013 May;10(2):103-11. DOI: 10.2174/1567202611310020003.

7. Abdullah Z, Rakkar K, Bath PM, Bayraktutan U. Inhibition of TNF- $\alpha$ protects in vitro brain barrier from ischaemic damage. Mol Cell Neurosci. 2015 Nov;69:65-79. DOI: 10.1016/j.mcn.2015.11.003.

8. Majid A, He YY, Gidday JM, Kaplan SS, Gonzales ER, Park TS, et al. Differences in vulnerability to permanent focal cerebral ischemia among 3 common mouse srtrains. Stroke. 2000 Nov;31(11):2707-14. DOI: 10.1161/01.STR.31.11.2707.

9. Shichinoke H, Kuroda S, Yasuda H, Ishikawa T, Iwai M, Horiuchi M, et al. Neuroprotective effects of the free radical scavenger Edavarone (MCI-186) in mice permanent focal brain ischemia. Brain Res. 2004 Dec;1029(2):200-6. DOI: 10.1016/j.brainres.2004.09.055.

10. Shichinoke H, Kuroda S, Abumiya T, Ikeda J, Kobayashi T, Yoshimoto T, et al. FK506 reduces infarct volume due to permanent focal cerebral ischemia by maintaining BAD turnover and inhibiting cytochrome c release. Brain Res. 2004 Mar;1001(1-2):51-9. DOI: 10.1016/j.brainres.2003.11.054.

11. Lowry OH, Rosebrough NJ, Farr AL, Randall RJ. Protein measurements with the folin phenol reagent. J Biol Chem. 1951 Nov;193(1):265-75.

12. Holmgren A. Purification of thioredoxin reductase from calf liver and thymus and studies of its function in disulfide reduction. J Biol Chem. 1977 Jul;252(13):4600-6.

13. Tamura A, Graham DI, McCulloch J, Teasdale GM. Focal cerebral ischemia in the rat: 2 . Regional cerebral blood flow determined by 14C-iodoantipyrine autoradiography foolowing middle cerebral artery occlusion. J Cereb Blood Flow Metab. 1981; 1(1): 61-9. DOI: 10.1038/jcbfm.1981.7.

14. Taxin ZH, Neymotin SA, Mohan A, Lipton P, Lytton WW. Modeling molecular pathways of neuronal ischemia. Prog Mol Biol Transl Sci. 2014;123:249-75. DOI: 10.1016/B978-0-12-397897-4.00014-0.
15. Ren Y, Wei B, Song X, An N, Zhou Y, Jin X, et al. Edaravone's free radical scavenging mechanisms of neuroprotection against cerebral ischemia: review of the literature. Int J Neurosci. 2015;125(8):555-65. DOI: 10.3109/00207454.2014.959121.

16. Manzanero S, Santro T, Arumugam TV. Neuronal oxidative stress in acute ischemic stroke: Sources and contribution to cell injury. Neurochem Int. 2013 Apr;62(5):712-8. DOI: 10.1016/j.neuint.2012.11.009.

17. Sanderson TH, Reynolds CA, Kumar R, Przyklenk K, Hüttemann M. Molecular mechanisms of ischemia-reperfusion injury in brain: Pivotal role of the mitochondrial membrane potential in reactive oxygen species generation. Mol Neurobiol. 2013 Feb;47(1):9-23. DOI: 10.1007/s12035-012-8344-Z.

18. Nagayama T, Lan J, Henshall DC, Chen, O'Horo C, Simon RP, Chen J. Induction of oxidative DNA damage in the peri-infarct region after permanent focal cerebral ischemia. J Neurochem. 2000 Oct;75(4):1716-28. DOI: 10.1046/j.1471-4159.2000.0751716.x.

19. Liu PK, Hsu CY, Dizdaroglu M, Floyd RA, Kow YW, Karakaya A, et al. Damage, repair, and mutagenesis in nuclear genes after mouse forebrain ischemia-reperfusion. J Neurosci. 1996 Nov;16(21):6795-806.

20. Olmez I, Ozyurt H. Reactive oxygen species and ischemic cerebrovascular disease. Neurochem Int. 2012 Jan;60(2):208-12. DOI: 10.1016/j.neuint.2011.11.009.

21. Takagi K, Kanemitsu H, Kohno M, Mitsuda K, Tomukai $\mathrm{N}$, Oka H, et al. Temporal profile of the superoxide dismutase and the ascorbic acid in focal cerebral ischemia. No To Shinkei. 1991 Nov;43(11):1075-80.

22. Sermet A, Taşdemir N, Deniz B, Atmaca M. Timedependent changes in superoxide dismutase, catalase, xanthine dehydrogenase and oxidase activities in focal cerebral ischemia. Cytobios. 2000;102(401):157-72.

23. Mahadik SP, Makar TK, Murthy JN, Ortiz A, Wakade $\mathrm{CG}$, Karpiak SE. Temporal changes in superoxide dismutase, glutathion peroxidase, and catalase levels in primary and peri-ischemic tissue. Monosialoganglioside (GM1) treatment effects.). Mol Chem Neuropathol. 1993 Jan-Feb;18(1-2):1-14. DOI: 10.1007/BF03160018.

24. Li X, Xiao Z, Han J, Chen L, Xiao H, Ma F, et al. Promotion of neuronal differentiation of neural progenitor cells by using EGFR antibody functionalized collagen scaffolds for spinal cord injury repair. Biomaterials. 2013 Jul;34(21):5107-16. DOI: 10.1016/j.biomaterials.2013.03.062. 
25. Hoffmann M, Schmidt M, Wels W. Activation of EGF receptor family members suppresses the cytotoxic effects of tumor necrosis factor-alpha. Cancer Immunol Immunother. 1998 Nov;47(3):167-75. DOI: 10.1007/s002620050517.

26. Ahnstedt H, Stenman E, Cao L, Henriksson M, Edvinsson L. Cytokines and growth factors modify the upregulation of contractile endothelin ET(A) and $\mathrm{ET}(\mathrm{B})$ receptors in rat cerebral arteries after organ culture. Acta Physiol (Oxf). 2012 Jun;205(2):266-78. DOI: $10.1111 /$ j.1748-1716.2011.02392.x.

27. García Del Barco-Herrera D, Martínez NS, CoroAntich RM, Machado JM, Alba JS, Salgueiro SR, et al. Epidermal growth factor and growth hormone-releasing peptide-6: combined therapeutic approach in experimental stroke. Restor Neurol Neurosci. 2013;31(2):213-23.

28. Guegan C, Ceballos-Picot I, Chevalier E, Nicole A, Onténiente B, Sola B. Reduction of ischemic damage in NGF-transgenic mice: correlation with enhancement of antioxidant enzyme activities. Neurobiol Dis. 1999 Jun;6(3):180-9. DOI: 10.1006/nbdi.1999.0240.

29. Larpthaveesarp A, Ferriero DM, Gonzalez FF. Growth factors for the treatment of ischemic brain injury (growth factor treatment). Brain Sci. 2015 Apr;5(2):165-77. DOI: $10.3390 /$ brainsci5020165.

30. Naylor M, Bowen KK, Sailor KA, Dempsey RJ, Vemuganti R. Preconditioning-induced ischemic tolerance stimulates growth factor expression and neurogenesis in adult rat hippocampus. Neurochem Int. 2005 Dec;47(8):565-72. DOI: 10.1016/j.neuint.2005.07.003.

31. Breitling R, Hoeller D. Current challenges in quantitative modeling of epidermal growth factor signaling. FEBS Lett. 2005 Nov;579(28):6289-94. DOI: 10.1016/j.febslet.2005.10.034.

32. Galvez-Contreras AY, Qui-ones-Hinojosa A, GonzalezPerez O. The role of EGFR and ErbB family related proteins in the oligodendrocyte specification in germinal niches of the adult mammalian brain. Front Cell Neurosci. 2013 Dec; 7:258. DOI: 10.3389/fncel.2013.00258.
33. Tu XK, Yang WZ, Chen JP, Chen Y, Ouyang LQ, Xu $\mathrm{YC}$, et al. curcumin inhibits TLR2/4-NF- $\kappa \mathrm{B}$ signaling pathway and attenuates brain damage in permanent focal cerebral ischemia in rats. Inflammation. 2014 Oct;37(5):1544-51. DOI: 10.1007/s10753-014-9881-6.

34. Tu XK, Yang WZ, Wang CH, Shi SS, Zhang YL, Chen $\mathrm{CM}$, et al. Zileuton reduces inflammatory reaction and brain damage following permanent cerebral ischemia in rats. Inflammation. 2010 Oct;33(5):344-52. DOI: 10.1007/s10753-010-9191-6.

35. Jin R, Liu L, Zhang S, Nanda A, Li G. Role of inflammation and its mediators in acute ischemic stroke. $\mathrm{J}$ Cardiovasc Transl Res. 2013 Oct;6(5):834-51. DOI: 10.1007/s12265-013-9508-6.

36. Katayama Y, Inaba T, Nito C, Ueda M. Neuroprotective effects of erythromycin on ischemic injury following permanent focal cerebral ischemia in rats. Neurol Res. 2016 Mar;38(3):275-84. DOI: 10.1080/01616412.2016.1138662.

37. Chen J, Wu X, Shao B, Zhao W, Shi W, Zhang S, et al. Increased expression of TNF receptor-associated factor 6 after rat traumatic brain injury. Cell Mol Neurobiol. 2011 Mar;31(2):269-75. DOI: 10.1007/s10571-010-9617-6.

38. Liu F, Chen MR, Liu J, Zou Y, Wang TY, Zuo YX, et al. Propofol administration improves neurological function associated with inhibition of pro-inflammatory cytokines in adult rats after traumatic brain injury. Neuropeptides. 2016 Mar 24. pii: S01434179(16)30027-0.

39. Fan L, Young PR, Barone FC, Feuerstein GZ, Smith DH, McIntosh TK. Experimental brain injury induces differential expression of tumor necrosis factor- $\alpha$ mRNA in the CNS. Mol Brain Res. 1996 Mar;36(2):287-91. DOI: 10.1016/0169-328X(95)00274-V.

40. Doll DN, Rellick SL, Barr TL, Ren X, Simpkins JW. Rapid mitochondrial dysfunction mediates TNFalpha-induced neurotoxicity. J Neurochem. 2015 Feb;132(4):443-51. DOI: 10.1111/jnc.13008. 